University of Nebraska - Lincoln

DigitalCommons@University of Nebraska - Lincoln

2003

\title{
The Duality of Race and Gender for Managerial African American Women: Implications of Informal Social Networks on Career Advancement
}

Gwendolyn Combs

University of Nebraska - Lincoln, gcombs2@unl.edu

Follow this and additional works at: https://digitalcommons.unl.edu/managementfacpub

Part of the Management Sciences and Quantitative Methods Commons

Combs, Gwendolyn, "The Duality of Race and Gender for Managerial African American Women: Implications of Informal Social Networks on Career Advancement" (2003). Management Department Faculty Publications. 31.

https://digitalcommons.unl.edu/managementfacpub/31

This Article is brought to you for free and open access by the Management Department at DigitalCommons@University of Nebraska - Lincoln. It has been accepted for inclusion in Management Department Faculty Publications by an authorized administrator of DigitalCommons@University of Nebraska - Lincoln. 


\title{
The Duality of Race and Gender for Managerial African American Women: Implications of Informal Social Networks on Career Advancement
}

\author{
Gwendolyn M. Combs \\ University of Nebraska-Lincoln
}

\begin{abstract}
Research suggests that women have progressed in equalizing their representation, status, and earning power as managers in organizations. These improvements may not reflect the career advancement of managerial African American women. African American women contend with the convergence of race and gender in improving their organizational standing and career advancement opportunities. The literature on workplace social networks indicates that informal more than formal socialization systems are salient in advancing careers. Due to the duality of race and gender, African American women in managerial and executive positions may be forced into out-group status in terms of informal social networks. Informal social networks for managerial African American women may be less accessible and may operate under different dimensions than for their African American male and White female and male counterparts. Critical examination of the effect of the interaction of race and gender on informal networks of managerial African American women in organizations is needed.
\end{abstract}

Keywords: African American women, career advancement, informal networks, race, gender

Some millennium reports suggest that much progress has been made in $\checkmark$ the advancement of women in corporate management and upper-level positions. Women are reported to have made considerable strides in organizational representation including increased earning power, movement 
into managerial and executive-level positions, and increased presence in the boardroom (see Catalyst, 1999; U.S. Department of Labor, 1999). This picture, however, might not necessarily reflect the status of all women in managerial positions, particularly African American women in management (Bell \& Nkomo, 2001; Blake, 1999; Ferdman, 1999). The thrust of this article is to examine the relative position of managerial African American women based on the duality of their race and gender status. More directly, the effort here seeks to accomplish two goals: (a) to urge and encourage a resurgence in organizational research that uses a true pluralistic perspective by focusing on the different experiences of group-specific minority women and (b) to suggest informal socialization networks as a framework for examining the influence of race and gender on advancement opportunities of African American women.

Alderfer (2000) suggested that language concerning race and the subtleties of racial inference in decision making continues to manifest in organizations. In addition, Powell and Graves (2003) discussed continued genderbased inequities in spite of increasing workplace presence and participation of women. The works of these researchers do not speak specifically of the workplace difficulties of African American women. However, their work provides insights into the additive and/or interactive effect of race and gender. This duality is critical to our understanding of the position and quality of the participation of managerial African American women in the workplace. The duality of race and gender for African American women managers is perceived to influence participation and interaction in informal workplace socialization. Informal socialization systems refer to those relationships and contacts that facilitate access to career and social support. Such relationships and support can greatly affect career opportunities and advancement (Ibarra, 1993; Powell, 1999).

With the growing emphasis on inclusiveness, there is a tendency to subscribe to the view that there is little differentiation in the experiences of racial/ethnic minority group members (e.g. Hispanic Americans, Asian Americans, African Americans, and Native Americans). However, some writers suggest that the organizational circumstances for persons of differing racial/ethnic groups is divergent from those experienced by majority men and women (Bell \& Nkomo, 2001; Catalyst, 1999; Thomas, 2001). More specifically, a recent study by the John J. Heldrich Center for Workplace Development (2002) indicates that workplace environments operate differently for African Americans than for other racial/ethnic minority groups (e.g., Hispanics and Asians). The study shows that African Americans, more than other groups in the workplace, are most likely perceived as being unfairly treated in terms of promotion and opportunities for training, perceive more significant disengagement, and are perceived to be more of a target for discrimination at work. Moreover, being African American may affect access to and participation in informal networks in ways that are different from other racial/ethnic groups (Phinney, 1990). It is noted that the use of African 
Americans as the focus does not negate the potential for similarities in outcomes for other groups.

In addition, the data from several studies reveal the dissimilarity of the status of and advancement of African American women in comparison to White women. That is, the organizational experience for African American women operates differently than that of majority women (Blake, 1999; McCollum, 1998; Yoder \& Aniakudo, 1997). The intersection of race and gender is suspected to have a negative impact on the work experiences of African American women (Bell \& Nkomo, 2001; Lach, 1999). However, few studies have explored the intricacies of the combined impact of race and gender on the organizational life of African American women as opposed to White women.

The paucity of research on minority women has been noted by Catalyst's (1999) report and others (Bell \& Nkomo, 2001; Ferdman, 1999). The state of the literature coupled with the lesser level of advancement for managerial African American women compared to White women suggests a focus on the duality of race and gender and its relationship to work environments and advancement opportunities. It is hoped that this article will fill some of this void. More specifically, the purpose of this article is to decouple individual minority groups from the all-inclusive perspective of minority and gender research.

The examination of circumstances and concerns facing African American women calls for group-specific application. Managerial African American women do not generally see overt discrimination as a persistent problem in today's workplace. However, managerial African American women do experience covert discrimination and subtle prejudice, leading to a lack of psychosocial and instrumental support that can contribute to failure and reduce opportunity for career-enhancing informal networks (Bova, 2000).

The concept of career development within organizations is established in the occupational and management literature (Hall, 1996; Kanter, 1977; Murrell, Crosby, \& Ely, 1999; Schein, 1978). The theories under girding career research emphasize developmental stages (Super, 1980), individual characteristics (Tiedeman \& O'Hara, 1963), personality perspectives (Holland, 1985), and person-environment interactions (Hackett \& Betz, 1981; Krumboltz, 1979). Minor's (1992) review and summary of the major career theories indicate that opportunity for feedback, access to information, interactive learning processes, and conducive environments are four critical elements for individual success in career development and advancement.

Career content and process theories seem to relate more directly to the discussion of the interplay of race and gender with informal social networks and the subsequent effect on career advancement. For example, Lent and Brown (1996) applied social cognitive theory to career processes. Hackett and Betz (198 1) presented a model of self-efficacy expectations based on sex role socialization, proposing self-efficacy development as a determinant of career 
attainment for women. Similarly, Hackett and Byars (1996) illustrated how social cognitive concepts may operate on career development of African American women.

Burt (1992) and, more recently, Podolny and Baron (1997) made clear the relationship between career advancement and informal social networks. Podolny and Baron disaggregated types of informal social network ties to examine the effect of five network types (e.g., advice, strategic information, mentorship, social support, and buy-in) on promotions within a high technology firm. Their findings intimate that the "pattern of social relationships is a meaningful determinant of an individual's fate, including intraorganizational advancement" (p. 689). Moreover, the synthesis of the career development and informal social network theories with research related to women and minorities is succinctly summarized by Mehra, Kilduff, and Brass (1998), who stated that the "lack of access to informal networks may be one reason that women and minorities (e.g., African American women), who are entering organizations in unprecedented numbers, are still underrepresented, especially in upper-management ranks" (p. 441).

This article examines how workplace response to the dual minority status of African American women influences the work context that can impact career advancement. More directly, the convergent influence of race and gender on career advancement is discussed, focusing on how race and gender affect career advancement through their influence on accessibility and instrumentality of workplace informal social networks. Opportunities for future research are suggested.

\section{Method}

Three bodies of literature were reviewed, synthesized, and summarized for this article. The research on informal social networks, career development (generally and specifically regarding racial/ethnic minorities and women), and the literature that specifically addresses the organizational experiences of women, racial/ethnic minorities, and African American women were pertinent. Searches of articles and scholarly journals were conducted through electronic databases, including Business Source Premiere, PsychLit, and Academic Search Elite, and electronic journals JSTOR and Interscience/Wiley. In addition, a manual review was conducted of bibliographies of scholarly articles related to the topic of interest. Key words used in the informal social networks literature search included "informal social networks," "network analysis," "informal social networks and minorities," "African Americans," and "social networks." The career development literature was searched using key words "career development," "career theory," "African American women," "minority career development," and "careers and social networks." Key words to inform the search for the organizational experiences of relevant groups included "race," "ethnicity," "organizations," "women," and "dis- 
crimination." Articles from peer-reviewed journals formed the foundation for this article. Books, laboratory studies, field studies, and theoretical works were included for review. Propositions to guide future research are provided in this article.

\section{African American Women From Two Perspectives}

"Half the price but twice as nice" and "two for the price of one" are old adages that take on a new dimension as they are used to refer to the dual minority status of African American women. These phrases have been used to articulate the perceived advantage or "bonus standing" that race and gender afford to African American women in the workplace (Nkomo \& Cox, 1989). The dual minority status of African American women is construed as a condition that provides a decided competitive advantage in hiring and professional advancement. However, African American women who experience this phenomenon of race and gender give divergent accounts of what it is like being "Black and female" and how their work experiences, work relationships, and advancement are affected (Blake, 1999; Ferdman, 1999; Yoder \& Aniakudo, 1997).

The convergence of race and gender may not be a double advantage (Bell \& Nkomo, 2001; Nkomo \& Cox, 1989). African American women contend that being "Black and female" has a negative impact on career advancement (Bell \& Nkomo, 1994; Bova, 2000). African American women occupying and aspiring to management and executive positions are forced to encounter dynamics in the work environment that hinder rather than enhance their career prospects and achievement (Feagin \& Sikes, 1994; Ferdman, 1999; Nkomo \& Cox, 1989). The intersection of race and gender often results in workplace inequities that stem from racial and gender biases that permeate the everyday experiences of African American women as they perform and seek career advancement in organizations (Bell \& Nkomo, 2001; Golden, 2002).

\section{Interaction of Race and Gender}

The career and human resource management literature reflects the differential impact of race and gender on advancement potential of affected groups (Hackett \& Byars, 1996; Thomas \& Alderfer, 1989). However, the work experiences that affect managerial African American women are still poorly understood. References to the plight of minorities and women in management typically encompass situational parameters faced by minority men or White women (Lach, 1999).

The number of African American women entering managerial and professional occupations witnessed a 79\% increase from 900,000 in 1986 to 1.6 
million by 1996 (U.S. Department of Labor, 1997). However, research suggests the presence of racial differences in the career experiences of women and highlight the barriers that African American women face (Bell \& Nkomo, 1994,2001; Bowman, 1993). African American women managers with similar work experience and, in some instances, more education than White women managers seldom reap similar rewards. Labor statistics show that a larger percentage of African American women in the labor force has a college degree than their White female counterparts. However, African American women hold a substantially lower percentage of managerial positions (Catalyst, 1999; U.S. Department of Labor, 1997).

\section{The Disparate Effect of Race and Gender}

Ferdman (1999) indicated that existing research examining the disparate effects of race and gender treat race and gender as separate and distinct variables, implying that racial and gender components of identity can be delineated and operate independently. The interactive effect of both race and gender, as dual components of identity, has been virtually ignored.

Buchanan and Ormerod (2002) suggested that a forced or artificial separation of race and gender can create confusion in determining the potential cause of workplace problems encountered by African American women. Buchanan and Ormerod found that, when faced with racial and sexual harassment at work, African American women had difficulty separating race and gender or race versus gender issues in the discrimination they faced. The continued slow movement of African American women into management and executive positions further suggests that the convergence of race and gender may impose a stronger effect on personal and social interactions that impact advancement opportunities. In addition, African American women in managerial and executive positions have expressed the detrimental reality of differential treatment and advancement due to race and gender convergence (Bell \& Nkomo, 2001; Golden, 2002).

Yoder and Aniakudo (1997) referred to what they call an "omnirelevant inseparability of race and gender in social workplace interactions" (p. 325) for African American women. In their study of African American women firefighters, they reported a work context and social interaction patterns that were distinctively different for African American women than they were for White men and women and African American men firefighters. These patterns were negative, revealing the exclusion of African American women from informal social systems. The introduction of African American women into the ranks of firefighters resulted in bonds between White and African American men that served to exclude African American women firefighters. White female firefighters became members of the in-group by their ability to leverage their racial identification with White male firefighters to the exclusion of African 
American female firefighters. These and other examples described by Yoder and Aniakudo, show the potential effect of the convergence of race and gender in the work environment. African American female firefighters are negatively affected in terms of training, performance evaluation, group status, socialization, and professional advancement.

\section{Evidence of Barriers to Advancement for African American Women}

Managerial African American women face barriers to advancement in numerous ways. Of the women holding managerial and administrative positions in the private sector, White women comprise $86 \%$ of that group and African American women only 7\% (Catalyst, 1999). African American women experience lower promotion rates than White women managers (Bell \& Nkomo, 1994), occupational job segregation (Woody, 1992), pressures to modify sex and occupational roles (Simpson, 1984), different predictors for advancement between African American women and men (Nkomo \& Cox, 1989), early mandates to the necessity to work versus options for White women (Harley, 1997; Woody, 1992), and negative career outcome expectancies resulting from racism and sexism (Golden, 2002; Hackett \& Byars, 1996).

The earning power and job hierarchy of African American women illustrate the salience of the interaction of race and gender. In 1996, African American women in comparable positions with their race and gender counterparts earned $88 \%$ of African American men, 85\% of White women, and $62 \%$ of White men (U.S. Department of Labor, 1997). Generally, African American men and White women earn less than White men. The dual influences of race and gender place African American women at the bottom of the ladder for advancement and earning power (Bova, 2000). Managerial African American women are more likely to hold staff positions, whereas White women managers generally hold more line positions that more readily lead to career advancement (Bell \& Nkomo, 1994; Woody, 1992).

Cox and Nkomo (1990) reported a negative relationship between interracial socialization and promotion success of African American managers. Although their findings suggest an overwhelming alienation of African American women managers from informal socialization, few studies have sought to explain the basis or intricacies of this alienation and other exclusions. The implications of in-group and out-group status in informal workplace social systems and their influence on career advancement are important considerations in examination of the marginal career progression of African American women managers. The general nature and properties of informal social networks are presented next, followed by a discussion of the significance of informal socialization on the career advancement of managerial African American women. 


\section{The Nature of Informal Social Networks}

The social network metaphor is a commonly used descriptor for a number of aspects of personal interactions, patterns of influence, and resource exchange in organizations (Nohria \& Eccles, 1992). The socially constructed nature of organizations, in general, reflects a set of social relationships that bind individuals and influence behaviors in efforts to accomplish work-related tasks (Ibarra, 1995; Mueller, 1986). Social networks have been described in terms of their instrumentality and proximity (Lincoln \& Miller, 1979); structure, cognition, and power (Krackhardt, 1990); content (Brooke, 2002); tie strength (Granovetter, 1973); and relationship type in terms of friendship, advice, and communication (Baldwin, Bedell, \& Johnson, 1997). Career success and managerial advancement in organizations are impacted largely by the operationalization of social networks (Tichy, 1981).

\section{Informal Versus Formal Networks}

Informal socialization incorporates what Ibarra (1995) referred to as "the set of job-related contacts that a manager relies on for access to task-related, career and social support" (p. 674). Informal social networks have been pinpointed to be just as important, if not more so, than the formal network in the accomplishment of macro (e.g., organizational level) and micro (e.g., individual level) goals and objectives (Burt, 1992). Informal social networks are positively linked to intra-organizational mobility (Podolny \& Baron, 1997), occupational attainment (Montgomery, 1992), individual and group performance (Sparrowe, Liden, Wayne, \& Kraimer, 2001), power and influence (Ibarra, 1993), and career advancement (Granovetter, 1973).

Formal and informal networks are distinguished by their composition, origin, and interaction patterns (Tichy, 1981). Formal networks represent the more prescribed links among and between organizational members emanating from official organization structure (e.g., organizational charts, supervisor/subordinate relationships, standing committee and advisory structures, and designated legitimate authority). In contrast, informal or emergent networks refer to voluntary associations and interactions (e.g., lunch groups, professional organizations, social outings) that do not necessarily have explicit authority or sanction of the organization and that may or may not operate in tandem with the prescribed (formal) patterns of interactions (Conway, 2001; Ibarra, 1995; Tichy, 198 1).

Informal social networks develop to facilitate the execution of task-related organizational objectives and social/personal objectives of participants. Both instrumental and psychosocial support can be the outcome of informal network participation. In addition, informal networks develop out of purposive self-interest of organizational actors (Ibarra, 1993), are reactions to opportuni- 
ties and problems of the work environment (Conway, 2001), and incorporate relationships that develop in conjunction with job-related functions but carry over into activities and interactions outside the usual and customary sphere of work roles.

\section{Properties of Informal Social Networks}

Many of the properties of informal social networks are important in the discussion of the impact of race, gender, and informal networks on career advancement (Ibarra, 1995; Tichy, 1981). Informal social networks may show similarities and differences across the following properties: Homophily: the degree of similarity in identity and group affiliations; range: the degree of diversity among all network participants; density: network depth and extensiveness; centrality: the degree of an individual's connectedness across all members and control of resource distribution; multiplexity: the extent of multiple role relationships among members; and tie strength: the degree of intimacy, reciprocity, and emotional intensity of relationships (Conway, 2001; Granovetter, 1973; Ibarra, 1993, 1995; Sparrowe et al., 2001).

The significance of informal social networks rests with the networks' influence on access to valued resources offering instrumental benefits and psychosocial support to network members. These resources positively relate to individual performance and career advancement opportunities (Cox \& Nkomo, 1991). Previous research has examined the differential networks of men versus women (see Brass, 1985; Nieva \& Gutek, 1981; Powell, 1999). And the dissimilarities of networks of minorities versus Whites have been studied (see Brutus \& Livers, 2000; Cox \& Nkomo, 1990; Fernandez, 1991; Ibarra, 1995; Thomas, 1993). In addition, a few studies (Bell \& Nkomo, 2001; Yoder \& Aniakudo, 1997) have explored the perception of managerial African American women of their informal interaction networks. It is argued here that the influence of race and gender on career advancement can be explained through examining their effect on access to and instrumentality of informal workplace social systems.

\section{The Intersection of Race, Gender, and Informal Social Networks}

The salience of the nexus between informal socialization processes and success in career advancement has been supported earlier in this article. However, studies of access to and dimensions of informal social networks for minority and women managers have netted mixed results. Some report that White women experience gender-based exclusion from such processes (Gattiker \& Larwood, 1990), whereas others suggest that White women perceive acceptance into informal socialization structures (Bell \& Nkomo, 1994). Mi- 
nority managers, particularly African American female managers, express perceptions of isolation and exclusion from informal networks (Bell \& Nkomo, 2001). Bova (2000) suggested that for African American women in professional positions, access to formal and informal networks may positively influence their career mobility, advancement, and success. The Catalyst (1999) study reports that $40 \%$ of the African American women surveyed stated that their advancement is inhibited by a lack of informal networks and social systems in the workplace.

The import of informal socialization to career advancement (Podolny \& Baron, 1997) and the identification of social politicking as a successful promotion strategy for managers (Luthans, 1988) make the examination of informal social systems all the more critical and relevant to our understanding of the work experiences of African American women managers and manager aspirants. The development of informal social networks for African American women may evolve differently from those of White men, White women, and African American men as a function of differential contextual experiences (Hackett \& Byars, 1996). Insights into informal socialization experiences of African American women as a matter of context may increase our knowledge of the impact of race and gender on significant antecedents of career advancement.

Informal socialization mechanisms frequently segment organizational participants into in-group and out-group status. Feagin and Sikes (1994) suggested that individual access to and participation in informal socialization systems are likely to have racial connotations. The out-group status of African American women results in their exclusion from many informal systems and associated knowledge and information exchange. The exclusion may impact job involvement, which is a precursor to career advancement (Nkomo \& Cox, 1990). Ilgen and Youtz (1986) noted the "lost opportunity effect" of out-group status that results in African American women managers having reduced chances for career-enhancing work. This ultimately lessens skill development that impacts advancement opportunities.

\section{The Minority Manager and Informal Socialization Processes}

Generally, minority managers tend to engage in fewer intimate informal systems than White managers (Ibarra, 1995). When developmental support is sought, there is a preference for more racially homogeneous interactions. This preference for homogeneous interactions often results in informal socialization with others external to their work units or organizations (Ibarra, 1993; Thomas, 1993). Such external interactions are useful in providing needed emotional support. However, such interaction outside of the work unit or organization may not afford occupational support leading to information and clarification pertinent to advancement in the work setting. African American 
female managers experience lower acceptance rates into informal social networks by both male and female White peers (Bell \& Nkomo, 1994). On the other hand, White female managers report more social acceptance and inclusion into interpersonal networks of their White male peers. This acceptance is positively related to White female manager's career advancement. Feagin and Sikes (1994) suggested that the African American female manager might be "seen as a temporary aberration in situations where Whites, male and female, are not predisposed to relinquish stereotypes and feelings of racial superiority. Moreover, the African American female manager might be perceived in competitive terms" (p. 172).

Lincoln and Miller (1979) argued that attributes associated with organization position have a segregating effect on ties between organizational members. More specifically, persons in low-status positions have ties to higher status individuals by way of the formal and informal organizational structure and formal reporting relationships. Thus, rank within the organization shapes the communication networks between and among members. Consequently, the segregation of African American women managers in lower status positions (Bell \& Nkomo, 1994) directs, to a large degree, their accessibility to informal interactions with higher-level organization members who may positively influence career advancement.

The lower status of managerial African American women in terms of position level and pay may reflect access and interaction dimensions of informal social networks in the workplace. Structural inequalities and institutionalized race and gender discrimination undoubtedly spill over into organizational socialization systems (Greenhaus, Parasuraman, \& Wormley, 1990). Furthermore, White men seem to be more accepting and appear to relate better to White women than to African American women in the workplace (Golden, 2002). Interaction networks have the power to create and perpetuate race and gender inequities. The status of informal social contacts becomes critical to the advancement goal (Ibarra, 1993). In their efforts to succeed in managerial and executive positions, African American women face multiple barriers to participation in the informal social arenas that contribute to successful career advancement (Bell \& Nkomo, 2001; Cose, 1993; Simpson, 1984).

\section{Racial Differences in Instrumental Relationships}

The status of African American managers in career progression has improved over the past decade. Regulatory and competitive mandates internal and external to some organizations have resulted in affirmative steps to hire and promote African Americans in managerial positions. Statistics on relevant representation of African Americans in management would be customary at this point; however, statistics alone do not reflect the realities of life behind the numbers. In spite of the advances made by African American 
managers, they perceive that "all is not right" with their experiences in organizations (Collins, 1997; Grossman, 2000).

Cose (1993) and Feagin and Sikes (1994) offered a myriad of recordings of African American managers who would normally be considered highly successful within corporate structures. This research provides compelling accounts of differential treatment, overall exclusion and isolation in the workplace, and career advancement not commensurate with their knowledge, skills, and abilities. In some cases, the chilling effects of disparity in opportunities in instrumental relationships temper the positive experiences of African American managers (Bell \& Nkomo, 2001; Dickens \& Dickens, 1991; TalleyRoss, 1995). Research offers substantial support for the feelings and perception of African American managers about their work environments. Examination of the circumstances surrounding African American employment suggests that although positive change has occurred, many aspects remain the same. The work environment of managerial African Americans continues to reflect race as a negative factor (Alderfer, 2000; Grossman, 2000; John J. Heldrich Center, 2002; Thomas, 2001).

The organizational context in which informal socialization processes are embedded causes the networks of African American women mangers to differ from those of White women managers (Ibarra, 1993), and it causes African American managers to perceive less career support (Cose, 1993). According to Lincoln and Miller (1979), race affects the formation, alignment, and proximity of primary and friendship ties. In these situations, there is a negative effect on the flow of information, access to resources, and the enjoyment of opportunities for advancement.

The out-group status of African American women mangers is an antecedent to their poor integration into informal social systems (Igbaria \& Wormley, 1992). Fernandez (199 1) found that African American managers, since his initial studies in 1976, continue to see their exclusion from informal activities of their work groups as a major problem and inhibitor to their career advancement. African American managers perceive race as a major factor in their experiences of workplace discrimination (Ferdman, 1999). However, the dual status of African American women managers suggests experiences in which the combination of race and gender might result in more debilitating affects.

Although blatant, overt acts of racial discrimination have waned, covert and more subtle forms of discrimination continue (Cose, 1993; Grossman, 2000). Socialization and positive collegial interactions are particularly hindered when White peers only speak to African American managers when they are spoken to and attempted to avoid any unnecessary contact. In spite of sensitivity, awareness, and diversity training, African American managers still perceive the requirement to be 3 times as competent as Whites to succeed (Fernandez, 1991) or, as expressed by Bell (2002), "the need to be twice as good ... to get half as far" (p. 198). They shoulder the burden of educating 
Whites on racial matters and adjusting their behaviors and attitudes to be at least partially accepted by their White counterparts (Bova, 2000; Brief et al., 1994).

Finally, affirmative action and equal employment opportunity programs designed to assist in the elimination of access and treatment disparity may be perceived as problematic for some organization members. The stigma of African Americans as "affirmative action hires" may operate to negate the skills and qualifications they bring to their positions. Informal socialization may be hampered because African Americans are seen as unqualified and resented for their seemingly forced inclusion in the organizational structure. These stigmas of African Americans existed, however, prior to the establishment of affirmative action and equal employment opportunity (see Myrdal, 1944). Although these may be the general perceptions of African Americans in the workforce, the concern that surfaces is to what extent these generalities pertain to the conditions governing the interface of African American women managers in the workplace.

\section{Gender Differences in Instrumental Relationships}

As previously stated, several variables have been identified as influencing career advancement for all managerial aspirants. The particular differences in the career advancement of women managers suggest that other variables are at play. When variables such as educational attainment, age, and organization tenure (Gattiker \& Larwood, 1990) are held constant, gender becomes the primary factor (Ohlott, Ruderman, \& McCauley, 1994). As a whole, women appear to encounter more barriers than men in obtaining developmental opportunities and exposure that make them prime candidates for advancement opportunities. These include job segregation, lack of developmental opportunities, social network exclusion, and sex-/gender-role bias (Cohen, 2002; Ely, 1995; Powell, 1999; Ruderman, Ohlott, Panzer, \& King, 2002; Tharenou, Latimer, \& Conroy, 1994).

Martin, Harrison, and Dinitto (1983) specified traits that are attributable to successful outcomes for both women and men managers. A clear dichotomy exists, as follows:

$\begin{array}{ll}\text { Women } & \text { Men } \\ \text { Person-oriented } & \text { Outcome-oriented } \\ \text { Noncompetitive } & \text { Competitive } \\ \text { Nurturing } & \text { Demanding } \\ \text { Risk-averse } & \text { Risk-seeking } \\ \text { Task-oriented } & \text { Strategic-minded }\end{array}$


The listed traits associated with women are traditionally perceived as incompatible with managerial decision-making roles. The male model of characteristics is that which is most preferred for management roles. However, more recent research suggests that traits traditionally ascribed to women may be more appropriate for reaching maximum organizational effectiveness in a diverse contemporary workforce (Ettorre, 1992; Fernandez, 1991; Powell, 1999). In their study of gender influences, Tharenou et al. (1994) revealed a sequence of relationships that tend to impact the career achievement of women managers (i.e., career encouragement that increases training and access to development activities). Career encouragement and subsequent development activities are instrumental to the managerial advancement of women.

Informal social networks in organizations serve numerous functions including feedback and support about career choices (Nkomo \& Cox, 1990). Both of these can provide the encouragement needed that positively affect career advancement. Overall, women managers continue to receive less career encouragement than men (Ely, 1995). According to Cohen (2002), environments that display resentment, discrimination, and prejudice continue to affect female manager's relationships with individuals important for career advancement. These conditions contribute to the lack of encouragement and isolation that women managers experience in the work context. Such environments typically result in out-group status for women mangers, affording them less access and instrumental relationships in informal social systems (Nkomo \& Cox, 1990).

The above perception of lack of career encouragement and feelings of isolation may be particularly pertinent to the organizational life and advancement of managerial African American women. Centrality in informal socialization systems (i.e., involvement and status prominence) provides important opportunities for advice and support that often lead to career advancement (Gilbert \& Ones, 1998). In a sense, such networks form the bases for social resources for advancement (Ibarra, 1995). In large measure, the circumstances reported by African American women managers suggest not only access differentials between African American women managers and their White counterparts but centrality differences as well (Catalyst, 1999).

In interacting within the work environment, managerial African American women find that they must consciously become "schizophrenic" (Simpson, 1984). There are consequences for appearing to Whites as being "too Black" and to men as being "too female." The duality of being both African American and female may impact the ability and, to some degree, the desire to become a full participant of in-group social systems. Although this process may be similar for White women and perhaps African American men as well, each only confronts the need to reduce the cognitive dissonance resulting from bilateral differences. However, African American women managers must face the realities associated with a trilateral difference between themselves and White men, White women, and African American men. Consequently, some 
African American women managers choose not to participate at all or to marginally pursue full in-group status in informal social system (Golden, 2002; Hackett \& Byars, 1996).

\section{Issues for Future Research}

As previously discussed, research shows that informal socialization activities impact career advancement. Few studies have examined the convergence of race and gender on career advancement opportunities (Bell \& Nkomo, 1994; Cox \& Nkomo, 1991; Hackett \& Byars, 1996). In addition, no studies specifically examine the interaction of race and gender on informal social systems operating in organizations. The issue of African American women's career advancement, within the context of informal socialization systems, is twofold. First, does the combination of race and gender have a greater impact than race or gender on access to informal social networks for African American women managers? Second, within informal socialization networks, are patterns and dimensions of interaction different for African American women due to a negative synergistic effect of their race and gender status?

If separately race or gender negatively impact participation of managerial African American women in informal social networks, and subsequently their career advancement, then the combined impact of race and gender may have a more pronounced interaction effect (Bell \& Nkomo, 2001; Bova, 2000; Catalyst, 1999; Hackett \& Byars, 1996; Ibarra, 1995; Ilgen \& Youtz, 1986; Mehra et al., 1998; Nkomo \& Cox, 1990). Several propositions for study can be generated from this scenario, as follows:

1a. African American women managers will experience less access to informal social networks than White women managers.

1b. African American women managers will experience less access to informal social networks than White and African American male managers.

1c. The interaction of both race and gender for managerial African American women will result in significantly less access to informal workplace social networks than race or gender alone.

To understand the experiences and career advancement prospects of African American women managers within organizational social systems, it is important to examine how the convergence of race and gender may influence experiences and outcomes of African American women as a function of informal organizational networks. Critical elements of these socialization systems include intimacy of interactions, use of information, and degree of interaction related to business policy and strategy implementation (Ibarra, 1995). 
Patterns and dimensions in interaction as factors of in-group status can provide insights regarding perceived instrumentality of these social systems for African American women managers.

Thomas (1989) suggested that racial taboos and African American female and White male experiences in slavery results in ambivalence and less intense ways of interactions across racial and gender lines. Thus, the reasons for problems of interracial socializing, as found by Cox and Nkomo (1991), may be different for African American women managers than for White women and African American male managers. Instrumentality of the dimensions of informal social networks should be examined in terms that differentiate the basis of participation for African American woman in comparison to their White and African American male and White female counterparts (Bell \& Nkomo, 2001; Blake, 1999; Brutus \& Livers, 2000; Conway, 2001; Ferdman, 1999; Ibarra, 1993; McCollum, 1998; Yoder \& Aniakudo, 1997). The following is proposed:

2a. For African American women managers more than for African American male managers, race will negatively affect instrumentality of informal social networks and its relationship to career advancement.

2b. For African American women managers more than for White women mangers, gender will negatively affect instrumentality of informal social networks and its relationship to career advancement.

2c. Race and gender will interact to more negatively affect instrumentality of informal social networks than either race or gender for managerial African American women.

\section{Conclusion}

This article attempts to renew the focus on the effects of the dual minority status associated with being an African American women in the ranks of management and its salience to career advancement. Particularly, the effects of this dual status on access and instrumentality dimensions of informal social networks are critical issues when discussing career advancement opportunities for African American women. In 21st-century organizations seeking to embrace diversity, the understanding, identification, and articulation of the different experiences of African American women play well with concerns for effective human resource management. Research is lacking that examines race and gender together to determine their convergent effect on informal social systems and the instrumentality of such systems for career advancement for managerial African American women. When issues of race are focal, gender tends to be ignored. And, when issues of gender are focal, race tends to be ignored (Nkomo \& Cox, 1990). Therefore, career advancement for African 
American women has been approached from an either/or perspective, either race or gender, but not the interaction of both.

African American women walk a precarious tightrope in the managerial arena. They are destined to be categorized because of the duality of their status. They must maneuver the stereotypes that are associated with the double bind of race and gender (Yoder \& Aniakudo, 1997). The predisposed views of women held by men, as well as the biases that can accompany being African American in a White world, converge in the experiences of African American women in management. These foci perpetuate a dichotomy within the experiences of African American women managers that serve to both separate and intertwine.

The impact of being both female and African American is of particular importance when affecting informal social systems that are open and assessable to African American female managers (Gilbert \& Ones, 1998). Informal social systems provide information and feedback that are critical to career advancement and success. Accessibility to these networks is central to the success of African American women managers in their quest for more favorable status in terms of position level and earning power. In addition, having effective informal social networks, with sufficient intimacy and utility, may weigh heavily as a factor for career success of African American women managers.

\section{References}

Alderfer, C. (2000). National culture and the new corporate language for race relations. In R. T. Carter (Ed.), Addressing cultural issues in organizations beyond the corporate context (pp. 19-33). Thousand Oaks, CA: Sage.

Baldwin, T. T., Bedell, M. D., \& Johnson, J. L. (1997). The social fabric of a team-based MBA program: Network effects on student satisfaction and performance. Academy of Management Journal, 40(6), 1369-1397.

Bell, E. L. J. (2002, October). Seven strategies for winning at work. Essence Magazine, p. 198.

Bell, E. L. J., \& Nkomo, S. M. (1994). Barriers to workplace advancement experienced by African-Americans. Cambridge, MA: MIT Press.

Bell, E. L. J., \& Nkomo, S. M. (2001). Our separate ways: Black and White women and the struggle for professional identity. Boston: Harvard University Press.

Blake, S. (1999). At the crossroads of race and gender: Lessons from the mentoring experiences of professional Black women. In A. J. Murrell, F. J. Crosby, \& R. J. Ely (Eds.), Mentoring dilemmas: Developmental relationships within multicultural organizations (pp. 83-104). Mahwah, NJ: Lawrence Erlbaum.

Bova, B. (2000). Mentoring revisited: The Black woman's experience. Mentoring \& Tutoring, 8(1), 5-16.

Bowman, S. (1993). Career intervention strategies for ethnic minorities. Career Development Quarterly, 43, 14-25.

Brass, D. J. (1985). Men's and women's networks: A study of interaction patterns and influence in an organization. Academy of Management Journal, 28, 518-539. 
Brief, A. P., Buttram, R. T., Reizenstein, R. M., Pugh, S. D., Callahan, J. D., McCline, R. L., et al. (2002). In P. J. Frost, W. R. Nord, \& L. A. Krefting (Eds.), HRM reality: Putting competence in context (pp. 187-200). Upper Saddle River, NJ: Prentice Hall.

Brooke, H. (2002). The pervasive effects of network content. Academy of Management Proceedings, pp. 51-57.

Brutus, S., \& Livers, A. (2000). Network characteristics of African American managers: Empirical validation and training applications. International Journal of Training \& Development, 4(4), 287-294.

Buchanan, N. T., \& Ormerod, A. J. (2002). Racialized sexual harassment in the lives of African American women. Women \& Therapy, 25(3/4), 107-125.

Burt, R. S. (1992). Structural holes: The social structure of competition. Cambridge, MA: Harvard University Press.

Catalyst. (1999). Women of color in corporate management: Opportunities and barriers. New York: Author.

Cohen, C. F. (2002). Glass ceilings and glass slippers: Still stereotyping after all these years? In P. J. Frost, W. R. Nord, \& L. A. Krefting (Eds.), HRM reality: Putting competence in context (pp. 205-213). Upper Saddle River, NJ: Prentice Hall.

Collins, S. M. (1997). Black corporate executives: The making and breaking of a Black middle class. Philadelphia: Temple University Press.

Conway, S. (2001). Employing social network mapping to reveal tensions between informal and formal organizations. In 0. Jones, S. Conway, \& F. Steward (Eds.), Social interaction and organizational change: Aston perspectives on innovation networks (pp. 81123). London: Imperial College Press.

Cose, E. (1993). The rage of a privileged class. New York: HarperCollins.

Cox, T. H., \& Nkomo, S. M. (199 1). A race and gender gap analysis of the early career experience of MBAs. Work and Occupations, 18(4), 43 1-446.

Dickens, F., \& Dickens, J. B. (1991). The Black manager making it in the corporate world. New York: AMACOM.

Ely, R. S. (1995). The power in demography: Women's social construction of gender identity at work. Academy of Management Journal, 38(3), 589-634.

Ettorre, B. (1992, March) Breaking the glass ... or just window dressing? Management Review, pp. 16-22.

Feagin, J. R., \& Sikes, M. P. (1994). Living with racism: The Black middle-class experience. Boston: Beacon.

Ferdman, B. M. (1999). The color and culture of gender in organizations: Attending to race and ethnicity. In G. N. Powell (Ed.), The handbook of gender and work (pp. 17-33). Thousand Oaks, CA: Sage.

Fernandez, J. P. (199 1). Managing a diverse work force: Regaining the competitive edge. Lexington, MA: Lexington Books.

Gattiker, U. E., \& Larwood, L. (1990). Predictors for career achievement in the corporate hierarchy. Human Relations, 43(8), 703-726.

Gilbert, J. A., \& Ones, D. S. (1998). Role of informal integration in career advancement: Investigations in plural and multicultural organizations and implications for diversity valuation. Sex Roles, 39(9/10), 685-704.

Golden, M. (2002, October). White women at work. Essence Magazine, pp. 190-198.

Granovetter, M. (1973). The strength of weak ties. American Journal of Sociology, 6, 1360-1380.

Greenhaus, J. H., Parasuraman, S., \& Wormley, W. M. (1990). Effects of race on organizational experiences, job performance evaluations, and career outcomes. Academy of Management Journal, 33, 74-86. 
Grossman, R. J. (2000, March). Race in the workplace. HR Magazine, pp. 41-45.

Hackett, G., \& Betz, N. E. (1981). A self-efficacy approach to the career development of women. Journal of Vocational Behavior; 18,326-339.

Hackett, G., \& Byars, A. M. (1996, June). Social cognitive theory and the career development of African American women. The Career Development Quarterly, 44, 322-340.

Hall, D. T. (1996). The career is dead-long live the career. San Francisco: Jossey-Bass.

Harley, S. (1997). Speaking up: The politics of Black women's labor history. In E. Higginbotham \& K. Romero (Eds.), Women and work: Exploring race, gender and class (pp. 28-51). Thousand Oaks, CA: Sage.

Holland, J. L. (1 985). Making vocational choices: A theory of vocational personalities and work environment (2nd ed.). Englewood Cliffs, NJ: Prentice Hall.

Ibarra, H. (1993). Personal networks of women and minorities in management: A conceptual framework. Academy of Management Review, 18(1), 56-87.

Ibarra, H. (1995). Race, opportunity, and diversity of social circles in managerial networks. Academy of Management Journal, 38, 673-703.

Igbaria, M., \& Wormley, W. M. (1992, December). Organizational experiences and career success of MIS professional managers: An examination of race differences. MIS Quarterly, pp. 507-528.

Ilgen, D. R., \& Youtz, M. (1986). Factors affecting the evaluation and development of minorities in organizations. In J. Rawland \& G. Ferris (Eds.), Research in personnel and human resource management (pp. 81-125). Greenwich, CT: JAI.

John J. Heldrich Center for Workforce Development. (2002). Work trends survey report. A workplace divided: How Americans view discrimination and race on the job. New Brunswick, NJ: Rutgers University.

Kanter, R. M. (1977). Men and women in the corporation. New York: Basic Books.

Krackhardt, D. (1990). Assessing the political landscape, structure, cognition and power in organizations. Administrative Science Quarterly, 35(2), 342-369.

Krumboltz, J. D. (1979). A social learning theory of career decision making. In A. M. Mitchell, G. B. Jones, \& J. D. Krumboltz (Eds.), Social learning theory and career decision making (pp. 19-49). Cranston, RI: Carroll Press.

Lach, J. (1999). Minority women hit a "concrete ceiling." American Demographics, 21(9), 18-21.

Lent, R. W., \& Brown, S. D. (1996). Social cognitive approach to career development: An overview. Career Development Quarterly, 44(4), 310-321.

Lincoln, J. R., \& Miller, J. (1979). Work and friendship ties in organizations: A comparative analysis of relational networks. Administrative Science Quarterly, 24, 181-199.

Luthans, F. (1988, May). Successful vs. effective real managers. The Academy of Management Executive, 2, 127-132.

Martin, P. M., Harrison, D., \& Dinitto, D. (1983). Advancement for women in hierarchical organizations: A multilevel analysis of problems and prospects. Journal of Applied Behavioral Science, 19(1), 19-33.

McCollum, V. J. C. (1998). Career development issues and strategies for counseling African Americans. Journal of Career Development, 25(1), 41-52.

Mehra, A., Kilduff, M., \& Brass, D. J. (1998). At the margins: A distinctiveness approach to social identity and social networks of underrepresented groups. Academy of Management Journal, 41, 441-452.

Minor, C. G. (1992). Career development theories and models. In D. H. Montross \& C. J. Shinkman (Eds.), Career development: Theory and practice (pp. 7-34). Springfield, IL: Charles C Thomas. 
Montgomery, J. D. (1992). Job search and network composition: Implications of the strength-of-weak-ties hypothesis. American Sociological Review, 57, 586-596.

Mueller, R. K. (1986). Corporate networking: Building channels for information and influence. New York: Free Press.

Murrell, A. J., Crosby, F. J., \& Ely, R. J. (1999). Mentoring dilemmas: Developmental relationships within multicultural organizations. Mahwah, NJ: Lawrence Erlbaum.

Myrdal, G. (1944). An American dilemma. New York: Harper \& Row.

Nieva, V. F., \& Gutek, B. A. (1981). Women and work. New York: Praeger.

Nkomo, S. M., \& Cox, T., Jr. (1989). Gender differences in the upward mobility of Black managers: Double whammy or double advantage? Sex Roles, 21(11/12), 825-839.

Nkomo, S. M., \& Cox, T., Jr. (1990, Winter). Factors affecting the upward mobility of Black managers in private sector organizations. The Review of Black Political Economy, pp. 39-57.

Nohria, N., \& Eccles, R. G. (Eds.). (1992). Networks and organizations: Structure, form and action. Boston: Harvard Business School Press.

Ohlott, P. J., Ruderman, M. N., \& McCauley, C. D. (1994) Gender differences in managers' development job experiences. Academy of Management Journal, 37(1), 46-67.

Phinney, J. S. (1990). Ethnic identity in adolescents and adults: A review of research. Psychological Bulletin, 108(3), 499-514.

Podolny, J. M., \& Baron, J. N. (1997). Resources and relationships: Social networks and mobility in the workplace. American Sociological Review, 62, 673-693.

Powell, G. N. (1999). Handbook of gender and work. Thousand Oaks, CA: Sage.

Powell, G. N., \& Graves, L. (2003). Men and women in management. Thousand Oaks, CA: Sage.

Ruderman, M. N., Ohlott, P. J., Panzer, K., \& King, S. N. (2002). Benefits of multiple roles for managerial women. Academy of Management Journal, 45(2), 369-386.

Schein, E. H. (1978). Career dynamics: Matching individual and organizational needs. Reading, MA: Addison-Wesley.

Sparrowe, R. T., Liden, R. C., Wayne, S. J., \& Kraimer, M. L. (2001). Social networks and the performance of individuals and groups. Academy of Management Journal, 44(2), 3 16-325.

Simpson, G. (1984). The daughters of Charlotte Ray: The career development process during the exploratory and establishment stages of Black women attorneys. Sex Roles, 2(1/2), 113-139.

Super, D. E. (1980). A life-span, life-space approach to career development. Journal of Vocational Behavior; 16, 282-298.

Talley-Ross, N. C. (1995). Jagged edges: Black professional women in White male worlds. New York: Peter Lang.

Tharenou, P., Latimer, S., \& Conroy, D. (1994). How do you make it to the top? An examination of influences on women's and men's managerial advancement. Academy of Management Journal, 37, 899-931.

Thomas, D. A. (1989). Mentoring and irrationality: The role of racial taboos. Human Resource Management, 28, 279-290.

Thomas, D. A. (1993). Racial dynamics in cross-race developmental relationships. Administrative Science Quarterly, 38, 169-194.

Thomas, D. A. (2001). The truth about mentoring minorities: Race matters. Harvard Business Review, 79(4), 98-1 12.

Thomas, D. A., \& Alderfer, C. P. (1989). The influence of race on career dynamics: Theory and research on minority career experience. In M. B. Arthur, D. T. Hall, \& B. S. 
Lawrence (Eds.), Handbook of career theory (pp. 133-158). Cambridge, UK: Cambridge University Press.

Tichy, N. M. (1981). Networks in organizations. In P. C. Nystrom \& W. H. Starbuck (Eds.), Handbook of organizational design: Remodeling organizations and their environments: Vol. 2 (pp. 225-249). Oxford, UK: Oxford University Press.

Tiedeman, D. V., \& O'Hara, R. P. (1963). Career development: Choice and adjustment. New York: College Entrance Examination Board.

U.S. Department of Labor, Bureau of Labor Statistics. (1999). Women in the workforce. Monthly Labor Review, 122(12).

U.S. Department of Labor, Women's Bureau. (1997). Update. Washington, DC: U.S. Department of Labor.

Woody, B. (1992). Black women in the workplace: Impacts on structural change in the economy. New York: Greenwood.

Yoder, J. D., \& Aniakudo, A. (1997). “Outsider within" the firehouse: Subordination and difference in the social interactions of African American women firefighters. Gender \& Society, 11(3), 324-341.

Gwendolyn M. Combs is an assistant professor of organizational behavior and human resource management at the University of Nebraska-Lincoln, where she received her Ph.D. in 2000. Her research focus is the effective acquisition and integration of employees in organizations. Her research interests include recruitment and selection, employee development, affirmative action programming, gender and diversity in organizations, self-efficacy, and leadership. She is also studying the implications of positive organizational behavior on human resource management issues. She has more than 20 years of executive and leadership experiences in human resource management with public, private, and governmental organizations. She consults in the areas of human resource planning, employee relations, recruitment and selection, affirmative action program planning, and diversity program development and training. 